\title{
The effect of Wireless (Wi-Fi) electromagnetic fields on oxidative stress in rat kidney tissues: A biophysical analysis
}

\section{Sıçan bölbrek dokularında elektromanyetik alanın oksidatif Kablosuz Biyofiziksel bir analiz

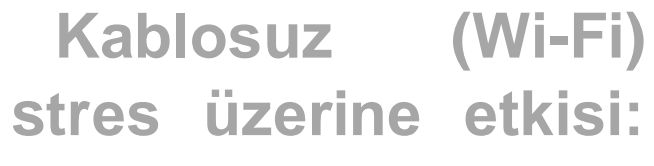

Recep Akkaya

Corresponding author: Recep Akkaya, MD, Department of Biophysics, Faculty of Medicine, Sivas Cumhuriyet University, Sivas, Turkey E-mail: recepakkaya5835@ gmail.com

Received/Accepted: February 02, 2020 / May 11, 2020

Conflict of interest: There is not a conflict of interest.

\section{SUMMARY}

The aim is to investigate the effect of melatonin on oxidative damage in rats exposed to Wi-Fi. This study aims to evaluate the effects of Wriless waves biophysically and biochemically. This study was to investigate the effects of Wi-Fi electromagnetic field (Wi-Fi-EMF) on total antioxidant status (TAS), total oxidant status (TOS) and oxidative stress index (OSI) in various rat tissues. In this study, we used 30 male Wistar Albino rats of 230250 grams of body weight. Animals were divided into five groups as control, saline ( $1 \mathrm{ml} / \mathrm{kg} /$ day olive oil for 30 days), Wi-Fi (12 hours/day for 30 days), melatonin (10 mg/kg/day for 30 days) and melatonin $+\mathrm{Wi}-\mathrm{Fi}(10 \mathrm{mg} / \mathrm{kg} / \mathrm{day}$ +12 hours/day for 30 days). In thirtieth day, thirty min after the last drugs administration at the indicated doses, PTZ was administered $45 \mathrm{mg} / \mathrm{kg}$ to induce epileptic seizure. The animals were observed for $30 \mathrm{~min}$. Seizure stages (according to the Racine Scale) and first myoclonic jerk times (FMJ). Twenty four hours after PTZ injection, kidney tissuss were collected for biochemical evaluation. Oxidative stress markers (total antioxidant status (TAS), total oxidant status (TOS) and oxidative stress index (OSI)) were measured in kidney tissues. In the control, no electromagnetic wireless exposure was applied. The quantities of TAS, TOS and oxidative stress index (OSI) in the collected kidney tissues were compared between the control and the exposure groups. Wi-Fi reduced antioxidant effect of melatonin $(\mathrm{p}<0.05)$. Moreover, Wi-Fi increased cell damage in kidney tissue $(\mathrm{p}<0.05)$. In terms of each parameter that is indicative for antioxidant levels and oxidant activity, there were significant differences between kidney tissues $(\mathrm{P}<0.05)$. This is a original study, due to the fact that by revealing in length the Wi-Fi effects of oxidative damage on kidney tissues of rats. Wi-Fi studies show that Wi-Fi causes oxidative stress and apoptosis. Wi-Fi directly reduced the effect of melotonin. The effects of Wi-Fi are caused by oxidative means.

Keywords: Biophysics model, electromagnetic waves, Wi-Fi, rat, TAS, TOS, OSI
Recep Akkaya

ORCID IDs of the authors: R.A. 0000-0002-3477-7198 
Amaç, Wi-Fi'ye maruz kalan sıçanlarda melatoninin oksidatif hasar üzerindeki etkisini araştırmaktır. Bu çalışma, Wriless dalgalarının biyofiziksel ve biyokimyasal olarak etkilerini değerlendirmeyi amaçlamaktadır. Bu çalışma, çeşitli sıçan dokularında Wi-Fi elektromanyetik alanının (Wi-Fi-EMF) toplam antioksidan durumu (TAS), toplam oksidan durumu (TOS) ve oksidatif stres indeksi (OSI) üzerindeki etkilerini araştırmaktır. Bu çalışmada, 230-250 gram vücut ağırlığına sahip 30 erkek Wistar Albino sıçan kullanıldı. Hayvanlar kontrol, (30 gün boyunca $1 \mathrm{ml} / \mathrm{kg}$ / gün zeytinyağı), Wi-Fi (30 gün boyunca 12 saat / gün), melatonin (30 gün boyunca $10 \mathrm{mg} / \mathrm{kg} /$ gün) ve melatonin + Wi-Fi (30 gün boyunca $10 \mathrm{mg}$ / kg / gün + 12 saat / gün). Belirtilen dozlarda son ilaç uygulamasından otuz dakika sonra otuzuncu günde, epileptik nöbet başlatmak için $45 \mathrm{mg} / \mathrm{kg}$ PTZ uygulanmıștır. Nöbet aşamaları (Racine Skalasına göre) ve ilk miyoklonik sarsılma süreleri (FMJ). PTZ enjeksiyonundan yirmi dört saat sonra biyokimyasal değerlendirme için böbrek dokuları toplandı. Böbrek dokularında oksidatif stres markerleri (toplam antioksidan durumu (TAS), toplam oksidan durumu (TOS) ve oksidatif stres indeksi (OSI)) ölçüldü. Kontrolde elektromanyetik kablosuz maruziyet uygulanmadı. Toplanan böbrek dokularındaki TAS, TOS ve oksidatif stres indeksi (OSI) miktarları kontrol ve maruziyet grupları arasında karşılaştırıldı. Wi-Fi, melatoninin antioksidan etkisini azalttı $(\mathrm{p}<0.05)$. Ayrıca, Wi-Fi böbrek dokusunda hücre hasarını arttırdı $(\mathrm{p}$ $<0.05$ ). Antioksidan düzeyleri ve oksidan aktivitesi için gösterge olan her bir parametre açısından böbrek dokuları arasında anlamlı farklılıklar vardı $(\mathrm{P}<0.05)$. Bu, oksidatif hasarın sıçanların böbrek dokuları üzerindeki Wi-Fi etkilerini uzun süre ortaya çıkarması nedeniyle orijinal bir çalışmadır. Wi-Fi çalışmaları, Wi-Fi'nin oksidatif stres ve apoptoza neden olduğunu göstermektedir. Wi-Fi, melotoninin etkisini doğrudan azalttı.

Anahtar sözcükler: Biyofizik modeli, elektromanyetik dalgalar, Wi-Fi, sıçan, TAS, TOS, OSI

\section{INTRODUCTION}

Wireless internet infrastructures have become one of the most preferred types of electromagnetic wave sources due to their ease of usage ${ }^{1}$. Although the effects of various technological instruments, such as mobile phones, televisions, microwaves, etc., are examined in various studies, there is a very small number of studies regarding the effects of wireless-induced electromagnetic waves (Wi-Fi RF-EMF) and wireless infrastructures on living beings $^{2}$. In recent years, especially in developed and developing countries, mobile phones have been widely used for communication purposes ${ }^{3}$. There are many studies showing that the electromagnetic field (Wi-Fi) emitted by base stations installed near the settlements has an adverse effect on the living tissues and their physiology ${ }^{4}$. The results of the study indicate that the Wi-Fi waves emitted by the mobile phone can cause significant health problems ${ }^{5}$. For this reason, many scientists have focused on this subject and have undertaken works to reduce the harmful effect of Wi-Fi waves ${ }^{6}$. Some of these studies indicated that the effects of electromagnetic waves on living organisms were important ${ }^{7}$, while some of them had reported no significant effects ${ }^{8}$.

New generation wireless communication technologies rapidly increase the levels of electromagnetic pollution in the world ${ }^{9}$. As is known, the same electric field in the environment even if it is increasing in frequency dependent conductivity of living tissues. Therefore, the amount of energy absorbed in tissue increases ${ }^{10}$. Mobile phones are mostly front or side pockets (close to the liver) is placed ${ }^{11}$. When it is carried around the waist, the fact that the mobile phone is close to the organs causes electromagnetic radiation and biological interactions between the internal organs ${ }^{12}$. Electromagnetic fields emitted by mobile phones, depending on where they are moved to be absorbed by various body organs ${ }^{13}$. Due to the high iron content of the liver, it is an easier target against the effects of electromagnetic fields ${ }^{14}$. This shows the importance of kidney and liver studies ${ }^{15}$.

Wi-Fi waves cause free radicals in living organisms and their longevity ${ }^{16}$. Free radicals and oxidative stress caused neuron damage. Antioxidants help cells in the destruction of free radicals ${ }^{17}$. Melatonin is a powerful antioxidant and more potent than other known antioxidants ${ }^{9}$. In the study, it was seen that melatonin (antioxidant activity) effect was decreased in rat kidney tissues exposed to Wi-Fi effect ${ }^{9}$. The antioxidant effect is reduced by Wi-Fi causing cellular damage ${ }^{9,18}$. In this study, the melatonin effect of Wi-Fi waves was evaluated with TAS, TOS and OSI values obtained from kidney tissue.

\section{MATERIAL AND METHODS}

\section{Animal Experimentations:}

All experimental protocols were performed in accordance with the guidelines of the Ethics Committee (65202830-050.04.04-145) . All experimental rats were kept in polypropylene cages at $20-22^{\circ} \mathrm{C}$ for 12 hours in the light / 12 hours in the dark. Melatonin was dissolved in physiological saline ${ }^{9}$. Melatonin was dissolved in physiological saline. Drugs were purchased from Sigma Alldrich. In the experimental study, we used $30230-250 \mathrm{~g}$ Wistar Albino male rats melatonin and Wi-Fi (30 days). Experimental rats Group 1: control, Group 
2: saline ( $1 \mathrm{ml} / \mathrm{kg} /$ day saline for 30 days), Group 3: Wi-Fi (12 hours / day for 30 days), Group 4: melatonin (five days) were divided into five groups. $10 \mathrm{mg} / \mathrm{kg} /$ day for 30 days) and Group 5: melatonin + Wi-Fi (10 mg / kg / day + 12 hours / day for 30 days). Melatonin, used as antioxidant, was accelerated according to the previous study ${ }^{9}$. Animal experimentations were conducted according to Akkaya R. et al. A common wireless internet router (Zyxel NBG- $418 \mathrm{~N} \mathrm{V2}$ wireless Access Point/Router) was used for Wi-Fi RFEMW exposure. The router was able to generate RF-EMW field at $2.4 \mathrm{GHz}$ and was working in 300 Mbps transmission rate. External electromagnetic field pollution was eliminated by placing the router and rat cages inside a Faraday Cage. Rats in were exposed to RF-EMW field of $2.4 \mathrm{GHz}$ frequency for 12 hours/day for 30 days. The dimensions of the Faraday cage was $800 \times 800 \times 800 \mathrm{~mm}$ and, the cage was made of copper wire. The $\mathrm{Wi}-\mathrm{Fi}$ router was located in the Faraday cage near the long edge of the cages.

Analysis of the Total Antioxidant Status (TAS), Total Oxidant Status (TOS) and Oxidative Stress Index (OSI):

Then rat kidney damages tissue were removed for biochemical evaluation. Kidney damages cell from each group was homogenized in ice homogenization buffer and centrifuged. The supernatant was collected, determined by a Bradford protein assay kit. TAS, TOS kit (Rel Assay Diagnostics ${ }^{\circledR}$ ) was used for TAS and TOS study. The TAS, TOS were analyzed by using the commercially sold Rel Assay TAS and TOS analysis kits were made to the method by Erel etal. The Rel Assay Diagnostics TAS and TOS Kit protocol were implemented according to the manufacturer's instructions. The oxidative stress index (OSI) was determined by the ratio of total oxidant status (TOS) to total antioxidant status $(\mathrm{TAS})^{9}$. The OSI level was calculated according to the following formula:

OSI (arbitrary unit) $=$ TOS/TAS x100

\section{Statistical Analyses:}

The data was built from a three-way data set. One Way ANOVA was implemented using SPSS 23 software to measure whether there was any difference between the groups. It is decided that the test has a difference between the groups according to the $5 \%$ significance level $(\operatorname{sig}=0,000<0.05)$.

\section{RESULTS}

\section{Biochemical results}

TAS and TOS were used to demonstrate the antioxidant and oxidative effects of melatonin. We increased TOS and OSI values in melatonin (Group 2), (Group 3), melatonin (Group 4) and Wi-Fi + and TOS and OSI values. Melatonin (Group 5) compared with control group (Group 1) (Table 1). Total antioxidant status was affected by melatonin supplementation and was not affected by Wi-Fi exposure.

Table 1: Effect of Wi-Fi and Melatonin on TAS, TOS and OSI in rat kidney damages tissue after PTZ induced seizures. Results are presented as mean $\pm \mathrm{SEM}$. ${ }^{\mathrm{a}} \mathrm{p}<0,05$ compared to control group, ${ }^{\mathrm{b}} \mathrm{p}<0,05$ compared to PTZ group and ${ }^{\mathrm{c}} \mathrm{p}<0,05$ compared to melatonin group.

\begin{tabular}{|l|l|l|l|}
\hline Group & TAS $(\boldsymbol{\mu m o l} / \mathbf{m g}$ & TOS $\quad$ protein) & OSI \\
\hline protein $)$ & $0,22 \pm 0,01$ & $0,68 \pm 0,02$ & \\
\hline Group1) & & & $363,22 \pm 13,58$ \\
\hline Group 2 & $0,23 \pm 0,00$ & $0,75 \pm 0,02^{\mathrm{a}}$ & $467,65 \pm 13,05^{\mathrm{a}}$ \\
\hline Group 3 & $0,24 \pm 0,01$ & $0,78 \pm 0,03^{\mathrm{a}}$ & $428,48 \pm 20,28^{\mathrm{c}}$ \\
\hline Group 4 & $0,27 \pm 0,00^{\mathrm{b}}$ & $0,81 \pm 0,01$ & $354,72 \pm 10,83^{\mathrm{b}}$ \\
\hline Group 5 & $0,24 \pm 0,00$ & $0,83 \pm 0,01^{\mathrm{a}}$ & $427,78 \pm 10,27^{\mathrm{c}}$ \\
\hline
\end{tabular}


In this study, we conducted a detailed study of the in vitro effects of electromagnetic waves from wireless technology on kidney rat tissues cell. In this study, the changes of TAS and TOS parameters showing oxidative stress were determined in kidney tissues cell of rats exposed to Wi-Fi EMF. In this study, increased OSI, TOS and decreased TAS values in renal rat tissues damages cell may be due to WI-Fi waves, although they are insignificant. We suggest that it can induce OSI from Wi-Fi and disrupt the function and structure of kidney tissues in rats exposed to these Wi-Fi devices. However, the relationship between the parameters used in our study and tissue damage is not certain. There was a statistically significant difference between control and Wi-Fi exposed groups ( $\mathrm{P}<0.05)$.

According to the current literature, there are many studies trying to determine the effects of EMG on organisms ${ }^{19}$. Longer studies are needed to obtain more accurate data.

\section{DISCUSSION}

In this study, $2.4 \mathrm{GHz}$ electromagnetic pollution increased oxidative stress in various tissues in rats. Differences in TAS, TOS and OSI values between test group and control were statistically significant in some tissues, but were insufficient to prove the effects of Wi-Fi exposure. In this study, biological effects of electromagnetic waves, antioxidant and oxidant capacities of kidney tissue, evaluation of various parameters of experimental and control groups and related statistics have been tried to be revealed with data. Biophysical analysis was performed with the help of data obtained from kidney tissue of Wi-Fi wave.

According to this biophysical analysis model, it is concluded that free radicals increase with Wi-Fi waves and decrease the effect of antioxidant substances. The proposed biophysical mechanism is discussed here.

\section{REFERENCES}

1. Cetin H, Nazıroğlu M, Celik O, Yüksel M, Pastacı N, Ozkaya MO. Liver antioxidant stores protect the brain from electromagnetic radiation (900 and 1800-MHz)-induced oxidative stress in rats during pregnancy and the development of offspring. J Matern Fetal Neonatal Med. 2014;27(18):1915-1921.

2. Dasdag S, Akdag MZ, Erdal ME, Erdal N, Ay OI, Ay ME, Yilmaz SG, Tasdelen B, Yegin K., Effects of $2.4 \mathrm{GHz}$ radiofrequency radiation emitted from Wi-Fi equipment on microRNA expression in brain tissue, International Journal of Radiation Biology, 2015; 91:(7), 555-561.
3. Frei P, Poulsen AH, Johansen C, Olsen JH, Steding-Jessen M, Schuz J. Use of mobile phones and risk of brain tumours: update of Danish cohort study. BMJ. 2011;343: 6387-6394.

4. Gilgun-Sherki Y, Melamed E, Offen D. Oxidative stress induced-neurodegenerative diseases: the need for antioxidants that penetrate the blood brain barrier. Neuropharmacology. 2001; 40:(8) 959-75.

5. Giray Aynali, Mustafa Nazıroglu, Omer Celik, Mustafa Dogan, Murat Yarıktas, Hasan Yasan, Modulation of wireless $(2.45 \mathrm{GHz})$-induced oxidative toxicity in laryngotracheal mucosa of rat by melatonin, Eur Arch Otorhinolaryngol, 2013; 270: $1695-1700$.

6. Hassanshahi A, Shafeie SA, Fatemi I, Hassanshahi E, Allahtavakoli M, Shabani M, Roohbakhsh A, Shamsizadeh A, The effect of Wi$\mathrm{Fi}$ electromagnetic waves in unimodal and multimodal object recognition tasks in male rats, Neurological Sciences, 2017; 38: (6): 1069-1076.

7. Durna Dastan S, Taslimi P, Gurses F, Akkaya R, Gökalp F, Gulcin İ. The Effects of Wireless on Carbonic Anhydrase and Acetylcholinesterase Enzyme Activities in Some Tissues Related to Respiratory, Excretory and Reproductive Systems of Rats. Cumhuriyet Medical Journal, 2019; 41 (1); $1-9$.

8. Hossmann KA1, Hermann DM. Effects of electromagnetic radiation of mobile phones on the central nervous system. Bioelectromagnetics. 2003; 24: (1) 49-62.

9. Akkaya R, Gümüş E, Akkaya B, Karabulut S, Gülmez K, Karademir M, Taştemur Y, Taşkıran AŞ, Wi-Fi decreases melatonin protective effect and increases hippocampal neuronal damage in pentylenetetrazole induced model seizures in rats. Pathophysiology. 2019; 26 (3-4); 375-379. doi: 10.1016/j.pathophys.2019.11.003.

10. Ítala Mônica Sales Santos, Adriana da Rocha Tomé, Gláucio Barros Saldanha, Paulo Michel Pinheiro Ferreira, Gardenia Carmem Gadelha Militão and Rivelilson Mendes de Freitas Oxidative stress in the hippocampus during experimental seizures can be ameliorated with the antioxidant ascorbic acid; Oxid Med Cell Longev. 2009; 2;(4) 214-221.

11. Levent Tök, Mustafa Nazıroğlu, Salih Doğan, Mehmet Cemal Kahya, Özlem Tök, Effects of melatonin on Wi-Fi-induced oxidative stress in lens of rats, Indian J Ophthalmol. 2014; 62: (1) 12 15. 
12. Liu LM, Wang N, Lu Y, Wang WP. Edaravone acts as a potential therapeutic drug against pentylenetetrazole-induced epilepsy in male albino rats by downregulating cyclooxygenase-II. Brain Behav. 2018; 1: 1156- 65.

13. Lun-Yi Zang, Greg Cosma, Henry Gardner, Val Vallyathan, Scavenging of reactive oxygen species by melatonin, Biochimica et Biophysica Acta (BBA). 1998;1425: (3) 469-477.

14. Lüttjohann A1, Fabene PF, van Luijtelaar G., A revised Racine's scale for PTZ-induced seizures in rats, Physiol Behav. 2009; 7: (5) 579-86.

15. Martin L.Pall, Wi-Fi is an important threat to human health, Environmental Research, 2018; 164: 405-416.
16. Meike Mevissen, Ulrich Ebert, Anticonvulsant effects of melatonin in amygdala-kindled rats, Neuroscience Letters, 1998; 257: (1) 13-16.

17. Guler G, Atalay NS. Functional enzymes of liver, total blood protein and albumin levels under electric fields. Med. Biol. Eng. Comput. Suppl. 1997; 1: 45- 54.

18. Watanabe Y, Nakagawa M, Miyakoshi Y. Enhancement of lipid peroxidation in the liver of mice exposed to magnetic fields. Ind. Health. 1997; 35: 285-290.

19. Guler G, Seyhan N, Aricioglu A. Effects of static and $50 \mathrm{~Hz}$ alternating electric fields on superoxide dismutase activity and TBARS levels in guinea pigs. Gen. Physiol. Biophys. 2006; 25: $177-$ 193. 